\title{
THE GOLDEN AGES OF PORN: THE 1970s (TRANSLATION INTO RUSSIAN) ${ }^{1}$
}

\author{
Shelton Waldrep \\ University of Southern Maine. Portland, USA. Email: waldrep[at]maine.edu
}

\begin{abstract}
This essay focuses on the brief moment in early seventies filmmaking when the porn industry made narrative-based films such as Deep Throat (1972) and Behind the Green Door (1972). This attempt to fuse porn with mainstream culture has come back into vogue in the present, when we see a new legitimization of porn. One might say that recent representations of sex on the screen have attempted to go back to the early seventies to restart a trajectory that was never able to complete itself. The essay begins with a consideration of the origins of porn films in nineteenth-century European art before moving on to the discussion of the seventies porn films and the complex way in which European art cinema influenced mainstream porn. Related to this topic are how cultural differences within countries influence the approach to sex that is expressed on the screen. In the US, the seventies full-length porn films legitimized certain sexual acts for their audiences and centered some of the pleasure on the screen on female desire as a way to expand the audience for porn. The essay concludes with a coda on the gay male cinematic equivalents of straight seventies porn films.
\end{abstract}

\section{Keywords}

cinema; pornography; mainstream; pornographic films; the 1970s

\section{(c) (i)}

This work is licensed under a Creative Commons «Attribution» 4.0 International License

1 The Editorial Board is very grateful to the author for granting the rights to translate and publish an excerpt of his book: Waldrep, S. (2021). The Space of Sex: The Porn Aesthetic in Contemporary Film and Television. Bloomsbury Publishing. 


\title{
ЗОЛОТОЙ ВЕК ПОРНОГРАФИИ: 1970-е ГОДЫ (ПЕРЕВОД НА РУССКИЙ ЯЗЫК) ${ }^{1}$
}

\author{
Уолдреп Шелтон \\ Университет Южного Мэна. Портленд, США. Email: waldrep[at]maine.edu
}

\section{Аннотация}

Данное эссе посвящено короткому отрезку времени в начале 70-ых годов, когда порноиндустрия производила такие сюжетные фильмы, как «Глубокая глотка» (1972 г.) и «За зеленой дверью» (1972 г.). Подобная попытка объединить порно с мейнстримной культурой происходит и в наши дни, когда мы становимся свидетелями новой легитимизации порно. Некоторые могут даже заметить, что новые сцены секса на экране возвращают нас в начало семидесятых годов, к возобновлению той траектории, которая пока не смогла найти своего завершения. Эссе начинается с рассмотрения корней порнофильмов в европейском искусстве XIX века, а затем переходит к обсуждению порнофильмов 70-ых годов и сложного характера влияния европейского арт-хауса на мейнстримное порно. Это тесно связано и с тем, как культурные различия между странами влияют на отношение к сексу, что также находит свое отражение на экране. В США полнометражные порнофильмы 70-х годов легитимизировали определенные сексуальные акты в глазах аудитории и частично перевели фокус экранного удовольствия на женское удовлетворение, в попытке увеличить аудиторию порнофильмов. Эссе завершается кодой о мужском гомосексуальном эквиваленте порнофильмов 70-х годов.

\section{Ключевые слова}

кинематограф; порнография; мейнстрим; порнофильмы; семидесятые годы

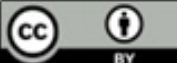

Это произведение доступно по пицензии Creative Commons «Attribution» («Атрибуция») 4.0 Всемирная

1 Редакция выражает признательность автору за предоставления прав на перевод и публикацию отрывка из книги: Waldrep, S. (2021). The Space of Sex: The Porn Aesthetic in Contemporary Film and Television. Bloomsbury Publishing. 
Пишущий о печально известной картине Гюстава Курбе «Происхождение мира» (1866), Барри Швабски отмечает, что такая композиция изображения с фокусом на женских половых органах, создаёт эффект фотографии, возможно чрезмерно порнографической для тех времен. Натуралистическая манера, в которой он изображает тело модели, в частности, усиливает ощущение фотореализма (Schwabsky, pp. 28-34) ${ }^{1}$. Премодернистская живопись Эдуарда Мане, возможно, чем-то обязана радикальному вычленению частей тела у Курбе и смелому стремлению такой подробной концентрации на теле ${ }^{2}$. Подобно тому, как философы, горнисты, старьевщики, любители абсента и, особенно, матадоры словно свободно парят в пространстве у Мане, без четкого фона и контекста, так и женское тело на картине Курбе, лежащее на кровати или диване, кажется, начинает свободно парить, предлагая модернистский отход реальности в пользу радикально абстрактного удаления всего, что не является необходимым для композиции.

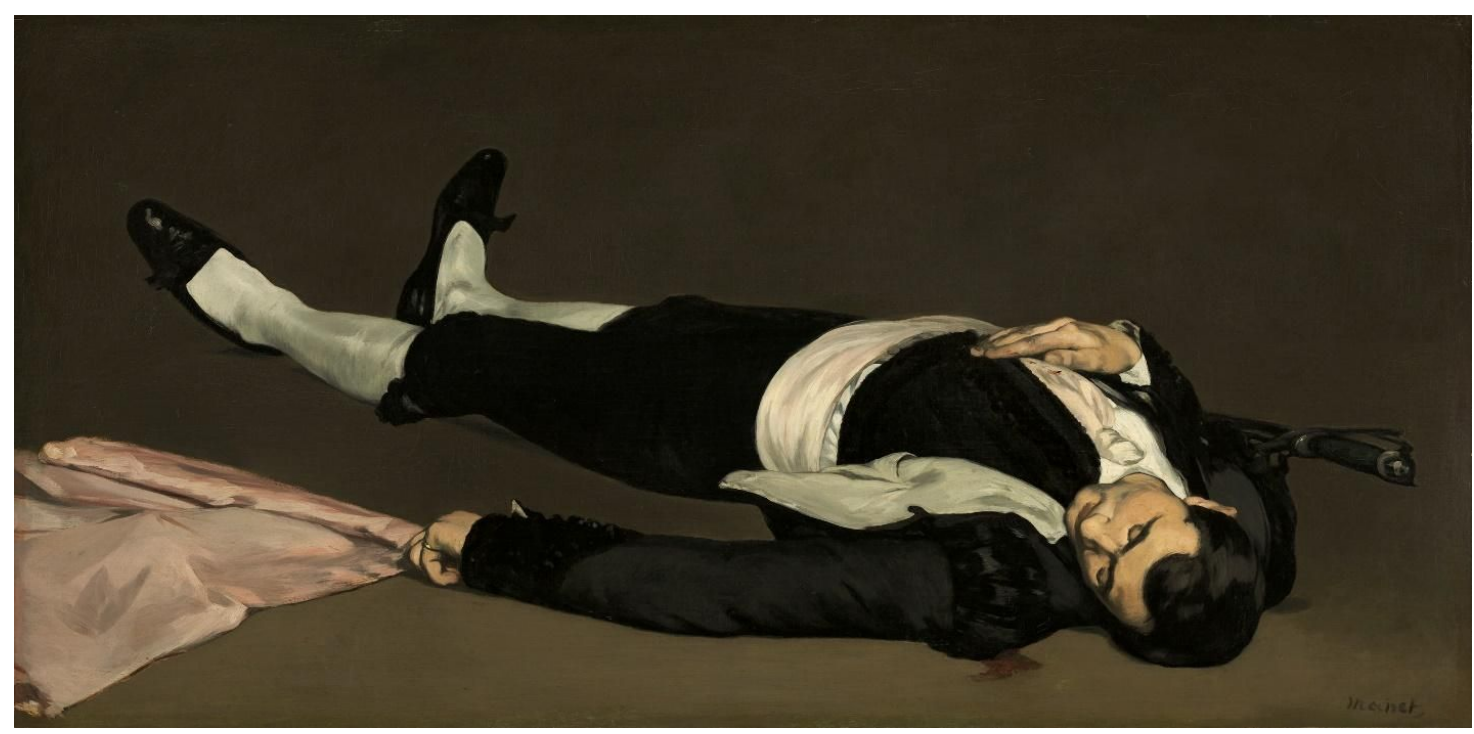

Рисунок 1. Эдуард Мане. «Мертвый тореадор» (1860-е годы) Figure 1. Édouard Manet. “The Dead Toreador" (1860s)

Курбе соединяет порнографию с технологией и заранее предвидит, как эта технология переопределит порнографию ${ }^{3}$ Сегодня провокация

1 Происхождение мира (1866 г.) можно увидеть и изучить по адресу https://www.museeorsay.fr/en/collections/works-in-focus/search/commentaire/commentaire_id/the-origin-of-theworld-3122.html.

2 Картину «Мертвый тореадор» (1860-е годы) и другие работы Эдуарда Мане можно более подробно рассмотреть на сайте https://www.nga.gov/collection/art-object-page.1179.html

3 «По мнению Фуко, Мане делал каждую картину комментарием к самой картине, что уже предрекалось перевернутым полотном Веласкеса, где живопись начала отходить от своей прежней и традиционной манеры проявления себя как смысла» (Soussloff, p.53). Именно это открытие возможности нового смысла в живописи, как отмечает Фуко, делает возможным не только живопись после импрессионизма, но и само современное 
Курбе выглядит как кадр из кинофильма или фотография из порножурнала 1970-х годов: кучерявые лобковые волосы модели - это такой же фетиш, как и все остальное в кадре ${ }^{4}$.

И если Курбе заглядывает в будущее кинотехнологии, то один из самых известных ранних теоретиков кино Андре Базен с большим трудом разделяет «эротизм» в кино, с тем, что происходит на сцене. Для Базена, секс выгоднее представлен в кино именно потому, что он завершается не на экране, а в сознании зрителя: «Потому что в отличие от театра, реального сценического пространства, основанного

искусство (р.54). Мане открывает концептуальное пространство между живописью как изображением объекта и живописью, становящейся самим объектом. Как и у Кубрика, картина образует сцену, которая в значительной степени представляет собой не совокупность изображений, а единое целое. Как объясняет Луи Марен, «референт не является непосредственным референтом из реального мира, так, например, вещь, на которую ссылаются, является не объектом мира, а самой сценой». Таким образом, вся сцена является референтом, что также является художественным артефактом. Но и сцена также является означающим, в котором означаемое, то есть изображенная форма, является живописным объектом, в котором она содержится» (Soussloff, p.40). Чтобы увидеть этот эффект, достаточно взглянуть на «тени, свет, пространства» на полотнах Мане (р.57). Как писал Фуко в своей главе о «Менинах»: «Здесь сам процесс репрезентации заключается в помещении одной из этих двух форм невидимости на место другой, в неустойчивом наложении, и в том, чтобы представить их обе в один момент на другом конце картины на том самом полюсе, который является самой вершиной изображения: на той самой глубине, в которой отразилась вся бездна художественного полотна» (Foucault, p.8). Включение Веласкесом зеркала в картину открывает «метатезу видимости, которая влияет как на пространство, представленное в картине, так и на его природу как на представление: позволяет увидеть в центре полотна то, что в картине необходимо, но вдвойне невидимо» (р. 8). Этот эффект особенно заметен в ранней склонности Мане к использованию черной краски, которая обеспечивает нестабильную глубину в картине - глубину, которая, кажется, выступает с поверхности навстречу зрителю. Для Фуко это также включает маскирующий эффект, который скрывает, в особенности, женскую сексуальность - от «Балкона» до «Олимпии» - и, возможно, больше всего, на картине «Бал-маскарад в Опере», «где черные маски на персонажах на картине маскируют и их индивидуальность» (Soussloff, p.64). Как и в работе Кубрика «Широко закрытыми глазами», картины Мане фиксируют то, что Фуко определяет как видимое и невидимое, но то, что мы можем также воспринимать как напряжение между фотографией и картиной, или фотографическим и событийным. Эти «слои» создают историю, которая является частью истории искусства (р.113).

4 Будь то арт-фильм или мейнстрим-порнофильм - пленочные фильмы 1970-х годов с появлением видеокассет и систем видеодистрибуции 1980-х годов стали чем-то совершенно иным. Как это часто отмечалось, возможность приватного просмотра порно коренным образом изменила сам жанр, что привело к появлению компакт-дисков, а затем, в конце концов, и к буму интернет-порно. В некотором смысле, интернет вернул нас к коротким роликам, отодвинув на второй план полнометражное кино. Кроме того, он позволил зрителям ознакомиться с порноклассикой, к примеру, 1970-х годов, хотя сейчас, по словам Дэвида Черча, она может рассматриваться как разновидность «винтажного» порно, подчеркивающая их «историчность» (р.132). Хотя порнография 1970-х годов помещена в контекст, подчеркивающий антураж периода, выкладывая «старую» порнографию рядом с современной порнографией, порносайты могут также показать универсальный, неизменный характер большинства половых актов. Такой контекст противопоставлен временному и вероятно странным образом утешает некоторых зрителей. Работа ученого или ценителей порно заключается в том, чтобы одновременно читать текст, подтекст и контекст старых порнофильмов. В случае с картинами 1970-х годов это означает чтение частей фильма только в пределах их первоначального театрального 
на сознании и конфликтах, кино существует в воображаемом пространстве, которое требует участия и отождествления. Отождествляя себя с актером, я испытываю удовлетворение от факта, что герой завоевал женщину. Его обольстительность, его красота, его смелость не соперничают с моими желаниями - они их исполняют» (Bazin, p. 174). Хотя Базен выступает за свободу кино, говоря, что «нет никаких сексуальных сцен, изображение которых было бы априори запрещено на экране», для того чтобы фильм был успешным там, где театр не сможет, он не должен показывать все, он должен быть абстрактным, чтобы быть эротичным (р. 174). Базен осознает важность стимуляции физической реакции зрителя для фильма, но выступает против логичного вывода, т.е. «идеализации порнографического фильма». Выход - пойти против реализма. К его чести, он также понимает «ограниченность» этого аргумента и завершает свое эссе призывом дать кино ту же свободу, которую мы предоставляем литературе: «Позволить роману описать все, но запретить кино показать все - это критическое противоречие, которое я отмечаю, не предлагая решения» (р. 175).

В некоторой степени, Ален Бадью подхватывает неразрешенное противоречие Базена, когда спрашивает: «Обязательно ли порнография - это профиль (specialty), а не жанр? И если да, то почему? Это особенно интересный вопрос в отношении самой сущности кинематографа, поскольку он входит в противоречие с полной открытостью сексуального» (р. 89) Как ранее задавался вопросом Бадью, каким был бы секс на экране, если бы его можно было «очистить» от влияния цензуры? Как бы мы могли исследовать связь между любовью и сексом? «Какую степень открытости можно допустить в отношении того, что, что можно назвать амурным телом?» (р. 88). Как и в случае с Базеном, что будет, если мы представим себе кино, в котором можно будет свободно выражать сексуальность и наготу? И хотя, как пишет Бадью, Жан-Люк Годар начал изучать эти возможности, «по этому поводу не было сделано ни одной убедительной работы» (р. 89).

Чтобы увидеть, что происходит, когда мейнстримное кино пытается принять сексуальность во всей ее свободе, стоит обратить внимание на короткий период в 1970-х годах, когда порнография и мейнстримное кино переплелись. Стремление снимать порнофильмы, отражающие набирающую силу сексуальную революцию, проявилось в виде мейнстримных фильмов для свиданий, которые смотрят молодые пары. Эти фильмы можно было увидеть в арт-хаусах ${ }^{1}$, прикампусных или

времени, но не как серию дискретных сцен, изолированных от остальной части произведения.

1 Речь идет о независимых кинотеатрах, специализирующихся на показе арт-хауса. (прим. переводчика) 
независимых кинотеатрах в крупных городских центрах. Существовал рынок подобных фильмов и места их показа. Эстетика порно слилась с техническим ноу-хау Голливуда и породила фильмы, нацеленные на некую респектабельность. Возможно, начиная с 1960-х годов и импортных шведских картин вроде «I Am Curious» (Желтый) (1967) и «I Am Curious» (Синий) (1968), кино в Америке стало более открытым относительно наготы и сексуальности. Европейские фильмы таких известных авторов, как Ингмар Бергман и Микеланджело Антониони, среди прочих, проложили дорогу второму поколению зарубежных фильмов, познакомивших американскую аудиторию с постоянно увеличивающимся сексуальным контентом (например, работы Нагисы Осимы) и отношением к сексу и телу, так контрастировавшими с американским пуританизмом. В итоге, особым шиком считалось не только подражать европейскому кино, но и порноиндустрии, что в свою очередь влияло на американскую киноиндустрию в целом ${ }^{2}$.

Порно 1970х начинается с фильма «Глубокая глотка» (1972). С него же начинается и недолгая история «порнофильмов для свиданий». В то время как многие иностранные фильмы часто обходили стороной грань между порнографией и массовым кино, или просто включали обычно нехарактерные для мейнстримного экрана порнографические элементы или наготу, «Глубокая глотка» был, по сути, порнофильмом, который некоторые пары смотрели в городских кинотеатрах. Несмотря на то, что фильм окружали скандалы, связанные с большой суммой денег, которую он принес (и кто получил или не получил эту прибыль), а также трагической судьбой Линды Лавлейс (она же Линда Борман), ставшей в итоге символом феминистского анти-порно движения (пока не отказалась от этой «должности»), картина изначально имела мало шансов на успех. С хронометражем чуть более часа, это кино лучше всего описать как фильм с одной шуткой. Гарри Римс играет роль доктора Янга. К нему обращается героиня Лавлейс, которая не способна получить оргазм. Выясняется, что ее клитор находится

2 Круз также утверждает, что фильмы изменились в ответ на толкование порно как чего-то, требующего «искупительной социальной ценности» (р.127). Можно сказать, что в этом смысле присутствовали попытки превратить порно в легальное искусство или, по крайней мере, замаскировать его, что повлекло за собой появление сюжета, улучшение игры актеров, использование более дорогих декораций и т.д.. Все это контрастирует с литературой, которая под влиянием судебных тяжб по поводу непристойности, вынуждена концентрироваться на истинной художественной ценности романа. Правда, этот юридический подход в итоге, возможно, привел к изменению порнографии в более художественную сторону - или, по крайней мере, к созданию более претенциозных фильмов. Массовый кинематограф видит сексуальную революцию как нездоровую, результатом чего является феминизм, движение за права гомосексуалистов и так далее. Кино 1960-х годов исключительно мизогинистично, но это изменилось в 1970-х годах, когда Голливуд перестал фокусироваться на обычных парах. 
в горле. И хотя она опечалена этим фактом, доктор убеждает, что, по крайней мере, он у нее есть, и его можно использовать. Решение ее проблемы, конечно, перекликается с названием фильма. И хотя сама по себе идея глупая, есть два аспекта, которые, возможно, делают фильм более приемлемым в качестве кроссовера. Абсурдность этой идеи придает фильму легкомысленный оттенок, что особенно заметно на фоне ужасной актерской игры Римса. Пока большая часть порнографии делает акцент на определенной серьезности, особенно если речь идет о порно, которое будут смотреть мужчины в присутствии других мужчин, и мрачный тон наводит на мысль, что мы говорим о маскулинном жанре, придурковатый тон «Глубокой Глотки», сознательно или нет, мягко пародирует жанр, частью которого картина является. Юмор снимает неловкое напряжение жанра и облегчает просмотр фильма в разнополых группах. Аналогично, хотя может показаться, что речь идет о мужском понятии irrumatio, позиция, которую занимает Лавлейс при исполнении полового акта, - это наклон поперек груди Римса. Данная поза призвана разместить героиню сверху, что противоположно тому, как мы воспринимаем героиню на коленях перед Римсом или свешивающей голову с кровати (две другие стандартные позы). Способ, которым снимается сам акт, безусловно, привлекает внимание к размерам Ривза, и, следовательно, к мастерству Лавлейс. Кроме того, в длинных крупных планах актёр почти полностью исчезает из кадра. Он становится органом, который сам по себе быстро исчезает в теле актрисы. Визуально он перестает существовать, пока голова Лавлейс доминирует на экране. Она сохраняет гораздо большую индивидуальность и субъектность, чем Римс. С точки зрения гендера, фильм облегчает зрительницам просмотр порно. В некоторой степени он преодолевает то, что может показаться двойным доминированием, которое предполагает для некоторых гетеросексуальный секс.

Фильм заканчивается предельно крупным планом рта Линды Лавлейс, напоминающего vagina dentata, который медленно крутится и переворачиваются, что является отсылкой к ее обычному положению относительно пениса. Этот несколько угрожающий образ пугает больше, чем веселит, наводя на мысль о сюрреалистичности фильма в целом, и в конечном счете, на странное сочетание чувственного и гротескного, сексуального и юмористического. Аномалия, которой стал фильм «Глубокая глотка», однако, на самом деле не сохранилась в порно. И хотя сейчас большинство порно-картин иронизирует над собственным тоном, осознанно привлекая внимание к плохой игре, реакцией 1970-х была попытка сделать более художественные версии порно: включая увеличение бюджета, сложности сюжета и, особенно, 


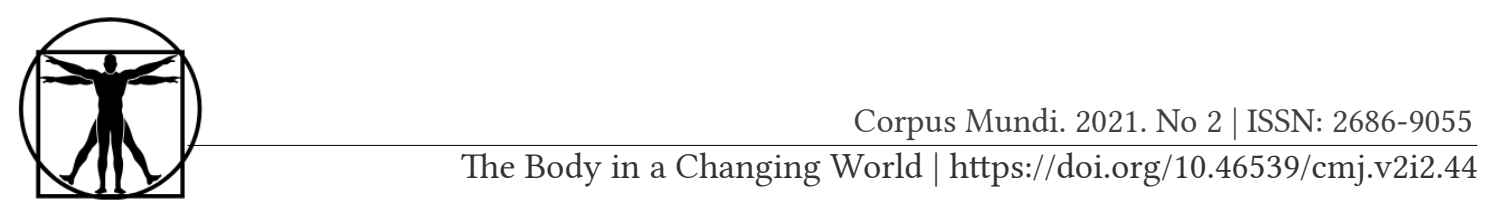

размытие границ между реальностью и фантазией, что создало своего рода порно-сюрреализм 1970-х годов. И хотя в итоге это направление привело появлению двух действительно прорывных порнофильмов «Открытие Мисти Бетховен» (1976) и «Радио Барбары» (1977), первые два фильма, которые появились на волне успеха «Глубокой глотки», «За зеленой дверью» (1972) и «Дьявол в мисс Джонс» (1973), дали дорогу не только более откровенным, но и к более претенциозным фильмам. «Дьявол в мисс Джонс» развивает идею женщины, исследующей собственное тело. Звезда фильма, Джорджина Спелвин, настолько болтлива, насколько молчалива Чэмберс. Фильм изображает анальный секс задолго до распространения моды на него. Возможно, даже он здесь появляется как дань уважения «Глубокой Глотке», так как фильм стремился сделать для него то же, что «Глубокая Глотка» сделала для орального секса. Сюжет разворачивается среди разнообразных сексуальных переживаний мисс Джонс. В конце сюжета - двойная пенетрация, которую полностью контролирует мисс Джонс, направляющая для своего удовольствия действия двух мужчин-любовников. Перед оргазмом она говорит: «Я хочу, чтобы вы кончили на меня». Последние кадры картины совпадают с первыми - поистине страшное изображение ада.

«За Зеленой дверью» напоминает «Глубокую Глотку» и «Дьявол в Мисс Джонс» неким акцентом на женском удовольствии. Сюжет включает в себя сказку внутри сказки. Водитель грузовика по имени Барри Кларк (Джордж С. Макдональд) останавливается в закусочной, где его и друга призывают рассказать историю о «зеленой двери» персоналу закусочной. Продолжая традиции вербального порно (от «Тысячи и одной ночи» до Рабле), «За зеленой дверью» сочетает в себе откровенность «Глубокой Глотки» и претензию на высокое искусство. Обрамление закусочной уступает место флешбэку, который порой больше напоминает представление, чем порнофильм. Тон истории, по мере повествования друга водителя, серьезен. «Сюжет в сюжете» мы видим с точки зрения Чэмберс. Она едет на спортивной машине в уединенный отель на озере где-то в северной Калифорнии. Водитель и его друг также остановились там. Она выходит на террасу отеля, пока двое друзей разговаривают, как сейчас в закусочной. Во время их беседы в ресторане на террасе впервые появляется главная героиня фильма. Подслушав разговор, она проявляет интерес к этим двум мужчинам), хотя и не разговаривает с ними (на самом деле, она так и не проронила ни слова за весь фильм). Чэмберс играет Глорию Сандерс, богатую женщину из Сан-Франциско, которая была похищена той ночью и доставлена на секс-шоу в театр в районе Норт-Бич, известном 
своими стриптиз-шоу. Ей был обещан полный сюрпризов эротический вечер. Позже Чэмберс рассказывала в интервью, что она действительно не знала, чего ожидать во время съемок (Marilyn Chambers). Чэмберс выводят на сцену через зеленую дверь. Она предстает перед аудиторией, состоящей из мужчин и женщин, которые вероятно пришли, чтобы получить удовольствие. Одетые в дорогую одежду, они также носят маски ${ }^{1}$. Постепенно они становятся все более возбужденными и без стеснения прикасаются друг к другу или к самим себе. Несколько минут хронометража отводится происходящему на сцене: группа женщин делает Чэмберс эротический массаж, переходящий в оральный секс. Следующий акт примерно такой же продолжительности показывает, как она занимается сексом с боксером Джонни Кизом, и это первая межрасовая секс-сцена в мейнстрим-порно (Williams, 2004, p. 299). В момент оргазма Чэмберс, Киз останавливается и уходит $^{2}$. Первые две секс-сцены подчеркивают удовольствие Чэмберс. И хотя вскоре это изменится, «За зеленой дверью» и «Глубокую глотку» роднит осознание важности женского удовольствия для секса или, по крайней мере, того факта, что гетеросексуальный секс - это улица с двусторонним движением. В следующей сексуальной сцене участвуют Чэмберс и четверо мужчин. Чэмберс поднята с помощью гигантской трапеции над сценой, на которой так же присутствуют трое мужчин. Чэмберс занимается оральным сексом с одним из них, параллельно удовлетворяя двух других мужчин. Четвертый мужчина вовлекает ее в вагинальный секс. Пока акцент удовольствия смещается с женского на мужское тело, фильм показывает камшот на протяжении большей части сцены. Наконец, фиксируясь на этом моменте, фильм в течение семи минут демонстрирует эякуляцию в замедленной съемке, в повторе, усиливающем зрительное восприятие и превращающемся в абстракцию - эякуляцию, пенис и лицо Чэмберс, все в разных цветах, намекая на состояние «под кайфом»³.

1 По словам Фредерика Раффаэля, Кубрик прислал ему в качестве возможного вдохновения для сценария фотографии Хельмута Ньютона, на которых изображены одетые мужчины и голые женщины (р.112).

2 В интересном прочтении сцены с Кизом, Круз рассматривает фильм через призму BDSM, a секс Киза с Чэмберс как «порнографию отмщения», «в которой расовое унижение берет главную роль» (Cruz, p.129). «Каким бы раздражающим ни был комментарий Киза, он выражает жажду мести, которая говорит о явных фантазиях расового насилия, оживляющих представления о черно-белом межрасовом сексе в современной порнографии» (р.130).

3 Камшот сам по себе играет сложную роль в экономике порнографической сцены. С одной стороны, он подтверждает реальность секса или, по крайней мере, оргазма актера, с другой стороны, он также разделяет персонажа на две части - эрегированный орган, который производит сперму, и лицо, которое изображает удовольствие. Субъектность актера фрагментирована на образы, крупные планы и детали (Аydemir, p.97). Камшот является примером как буквального повествования, заканчивающегося телосом (т.е. целью по 
Несмотря на всю отсрочку в изображении мужского удовольствия, фильм ясно показывает, что всякое порно в конечном итоге приводит к экстернализированному оргазму мужчины-актера. Одновременная стимуляция сразу четырех мужчин в конце концов приводит стиранию границ между участниками сцены и зрителями в зале. В театре разворачивается оргия, и жизнь врывается в искусство, когда рассказчик истории переносит Чэмберс обратно через зеленую дверь, возвращаясь в реальный мир. Фильм завершается вместе с рассказом водителя грузовика, покидающего закусочную и снова едущего за рулем своей машины. Однако теперь он вспоминает, что же произошло после «спасения» героини: мы видим, как Чэмберс и рассказчик занимаются любовью, на полу, в обычной обстановке. Тело Чэмберс сливается с кадрами ночи, звезд и дороги, параллельной ее телу, которое становится больше, чем жизнь.

Как и «Открытие Мисти Бетховен», «Зеленая дверь», похоже, намекает, что секс между мужчиной и женщиной завершается традиционным соитием наедине. Добавив к этому еще один уровень самоосо-

Аристотелю), так и замкнутого цикла, который никогда не заканчивается, но всегда возвращается и повторяется (р. 111). Линда Уильямс трактует камшот в гетеросексуальном порно как завершающий нарратив-акт (по своей универсальной линейности), но разделенная субъектность камшота также предполагает полиморфно-извращенное удовольствие от повторения и мастурбации. Неспособное показать женское удовольствие или подтвердить его - гетеросексуальное порно, стремящееся сделать женское удовольствие видимым, вынуждено обратиться к аналогу, перенося мужское удовольствие буквально на лицо партнера. Как камшот можно интерпретировать, например, в эджингпорно? Может ли этот жанр, показывая мужчину целиком, не членить сигнификат? Паттерсон рассматривает мужчин-актеров порно как личностей, гордящихся точностью своей игры и способностью кончить, когда и где им велят (Aydemir, p.115). В их демонстрации контроля присутствует некоторая инструментальность. Но если актеры получают власть от этого контроля, как их маскулинность формируется камшотом? Что это может означать для гей-порно, и опять же, как, например, эджинг-порно, где контроль якобы находится (буквально) в руках «хозяина»? И еще один способ взглянуть на камшот это через разрыв нарратива - внезапный момент самосознания, когда зрителю напоминают о том, что он смотрит фильм (р.126). Это также физическое явление, которое изменяет тело актера и делает видимым его участие в фильме совершенно иным образом (р.117). И совсем другое дело, привязывает ли оргазм актера или наоборот позволяет ему исчезнуть из фильма. Есть ли в этом определенный смысл или нет (р.119)? Имеет ли это значение? Поскольку маскулинность не находится в камшоте, она легко может витать над сценой (р.120) В конце концов, липкая субстанция не обязательно связана с пенисом (р.122). С другой стороны, отсутствие смысла может быть связано с материальностью семяизвержения и его зрительным восприятием, которое может быть приятным само по себе (р.127). Разрыв в реализме, которым является камшот, почти брехтианский, ибо он предназначен в основном для зрителей и, в конечном счете, дополняет цикл с ними обещание обратить на них внимание. В конце концов, камшот является формой мастурбации, которая вовлекает руку не в меньшей степени, чем фаллос. Если бы камшот снимался без участия рук или любого другого инструмента, то оргазм мужского тела показался бы приятным, ответной реакцией, а не активным и контролируемым (p.128). Тело может показаться уязвимым, окутанным спазмом наслаждения. Вместо этого камшот подвешивает маскулинность между реальной, неуклюжей материей - реальным семенем и инструментальностью образа (р. 133). 
знания, фильм, вероятно, утверждает, что настоящая цель порно служить прелюдией для гетеросексуальной пары. Это фантазия, «история», призванная акцентировать внимание на новизне и взаимном удовольствии. Фильм сочетает в себе прелесть кантримузыки и типичный американский роуд-муви с изображением некоторых уголков Сан-Франциско, привычных для режиссеров фильма Джима и Арти Митчеллов. Он хорошо снят и всячески подчеркивает красоту тел актеров. В своей концептуальной структуре фильм уравновешивает реализм (жесткий секс) с нарочито утаенными сюжетами, заставляющими аудиторию воспринимать себя как зрителей фильма и как вуайеристов. В этом смысле, он предвосхищает фильм «С широко закрытыми глазами» Стэнли Кубрика (1999), где в момент оргии одетые зрители смотрят на различные сложные сексуальные сцены, происходящие будто на сцене. Лица зрителей здесь также скрыты масками.

К преимуществам этого фильма стоит отнести минималистский подход, используемый кинематографистами. Секс, хотя и представлен, часто снимается под необычными, даже дезориентирующими для зрителя углами. Женское тело, пусть едва скрытое от посторонних глаз, часто изображается в отдельных деталях: например, в едва заметном соске, нежели в почти гинекологических кадрах, которые так любят некоторые порно-режиссеры. Акцент на женском удовольствии часто делается в виде куннилингуса, который здесь показан с избытком, и часто без изображения пениса. Расовая составляющая в выборе актеров, пожалуй, так же интересна, как и гендерная, хотя она, вероятно, сложнее и проблематичнее. Киз довольно явно позиционируется как «африканец» с искусно накрашенным лицом и костяным ожерельем, которое выбрал сам актер. Помимо этого, его единственным прикрытием является обтягивающее белье, разрез в котором делает акцент на размере его гениталий. Исследователь порнографии Линда Уильямс утверждает, что образ Киза представляет особый троп. Это были ранние приметы изменения восприятия афро-американского мужского тела с пугающего и табуированного на желанное, эротизированное и фетишизированное (Williams, 2004, р. 303). Для Уильямс эстетизированная африканская символика, которой отмечена роль Киза, должна была свидетельствовать о его «власти» (р. 300), и фильм предвидел появление откровенного межрасового «Мандинго» ${ }^{1}$ (1975), так и основной роли межрасового порно, которым в конце концов стали бы сцены межрасового секса. Она также утверждает, здесь и в других местах этого эссе, что межрасовый секс всегда предполагает отсутствие третьего - белого

1 Фильм, рассказывающий историю отношений чернокожего раба и белой девушки. (прим. редактора) 


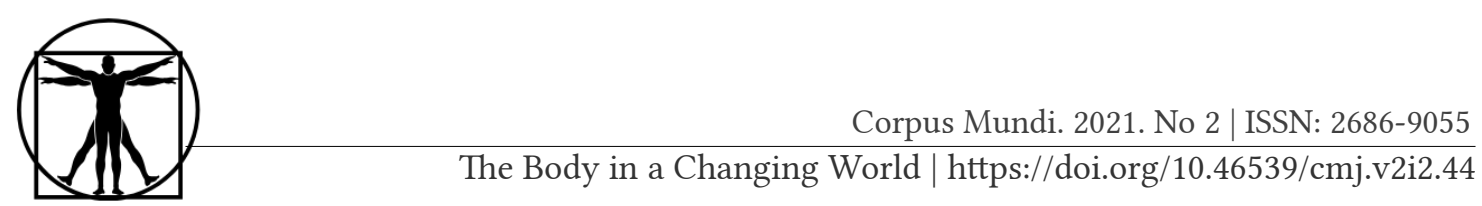

мужчины, с которым белая женщина не занимается сексом, как в этой сцене, или черной женщины, которая отсутствует в сценах между черными женщинами и белыми мужчинами (р. 300). В то время как Уильямс пытается доказать, что процесс превращения чёрных мужчин в сексуализированные объекты на самом деле длился десятилетия, я бы утверждал, что он достигает своего апофеоза в работах вроде «Чёрной книги» Роберта Мэпплторпа (1986), где белый гей фетишизирует своих влюблённьх, буквально превращая их в произведения искусства, выставляя их на стендах, чтобы ими одновременно восхищались и глазели на них. В то время как Уильямс недооценивает тревожный расизм, присущий этой игре со стереотипами, она делает это для того, чтобы подчеркнуть: порнографический элемент порно не спасает никого от объективизирующего взгляда. Человека загоняют в зону эротики, чтобы он мог видеть или быть увиденным сквозь эту оптику. Что важно в сцене между Кизом и Чэмберс, так это то, что она «работает», несмотря на свои маркеры расовых различий. Киз двигается так долго, что зритель забывает обо всем, кроме этой сцены интимности физического акта между исполнителями ${ }^{1}$. Братьям Митчелл удается снять сексуальные акты абстрактно и деконтекстуализировать их. Они становятся искусством перформанса, призванного усилить перфоманс. Парадоксально, но исполнители становятся более индивидуализированными, несмотря на то, что мы мало знаем о них. Они перестают быть тропами или типажами, становясь телами в пространстве, объединенными повествованием, которое происходит в реальном времени и на наших глазах.

Как рассказывает Рэймонд Дж. Хаберски-младший, известный кинокритик Эндрю Саррис, сделавший очень много для продвижения теории авторского кино в США, не одобрял моду на артхаусные порнофильмы именно потому, что художественное притворство, по его мнению, «уничтожало единственный подходящий для них контекст» (Harberski, p. 391), состоящий из «насыщенного искушения, деградирующего и неблаговидного... процесса» (цит. по Harberski, p. 391). Хотя Саррис воспринимал фильмы как историческое событие, он не видел ничего революционного в изображении секса в мейнстримных фильмах. Кажется, ему гораздо больше по душе была атмосфера 1950-х или начала 1960-х годов - «секс как разврат» в фильмах Джона Уотерса или классике пре-1970-х годов вроде байкерского фильма «Мочи, мочи их, киска!» (1965).

1 По словам Киза, он двигался 43 минуты (Pryor). 
В то время как Саррис, вероятно, больше предпочитал систему грайндхаусов ${ }^{1}$, другие кинокритики наслаждались порнофильмами, которые показывались в порнокинотеатрах на Таймс-сквер до того, как район был перестроен. Ричард Шикель, Ричард Корлисс и Брендан Джилл весьма поэтично отзывались об опыте просмотре порнофильмов в кинотеатре (Harberski, pp. 391-393). В условиях, когда новые порнофильмы, замещавшие старые, воспринимались как несостоятельная форма искусства или порно, наступление Золотого века порнографии, таким образом, было сложным процессом. Хотя порнофильмы, выпущенные в ту эпоху, могут сейчас рассматриваться как высокохудожественные, необходимо также помнить, что в какой-то степени порнография черпала вдохновение в артхаусных фильмах, не связанных с порнографией. Как отмечает Мария Ларссон, в картине «Девичий источник» (1960) и других фильмах 1960-х гг. Бергман не чурался сексуальной тематики, выставляя сексуальную и психологическую дисфункцию людей на показ более двадцати лет во многих своих фильмах (р. 25). Аналогично, в Италии снимается серии «Трилогия жизни» Пьера Пазолини, пересказывающие фрагменты из «Декамерона» (1971), «Кентерберийских рассказов» (1972) и «Цветка тысячи и одной ночи» (1974) как откровенные, наполненные сексуальностью моральные сказки о догреховных времена, когда тела были свободны от стыда и цельны в своем докапиталистическом состоянии, и эти фильмы были попыткой реконструировать тело, как некую альтернативу современному телу. Считается, что связь между мирами порно и художественного кино достигла своего апогея в конце 1960 -х - начале 1970-х годов, когда сексуальная откровенность и насилие «Бонни и Клайда» (1967) и «Я любопытна - жёлтый» (1967) были продолжены в фильмах «Полуночный ковбой» (1969), «Заводной апельсин» (1971), и «Последнее танго в Париже» (1973) (Harberski, p. 398). Популярные фильмы того времени также приобрели более сексуальный характер, распространив тематику на гомосексуализм, и, в конечном итоге, в 1970-е годы, интенсификация и повседневность сексуальной культуры часто изображалась в кино и на телевидении как естественное, даже провинциальное явление ${ }^{2}$. Поэтому нет ничего удивительного в том, что некоторые критики могут сравнивать порноклассику, такую как

1 Сейчас под этим термином подразумеваются кинотеатры, показывающие кино эксплуатационного жанра (т.е. снятое с целью быстрого заработка), ранее он подразумевал места (т.н. «театры бурлеска»), где можно было посмотреть стриптиз и т.п. (прим. ред.)

2 См., например, мою работу по «Бриллиантам навсегда» в четвертой главе книги «Растворение места: Архитектура, идентичность и тело» (The Dissolution of Place: Architecture, Identity, and the Body.) (прим. автора) 


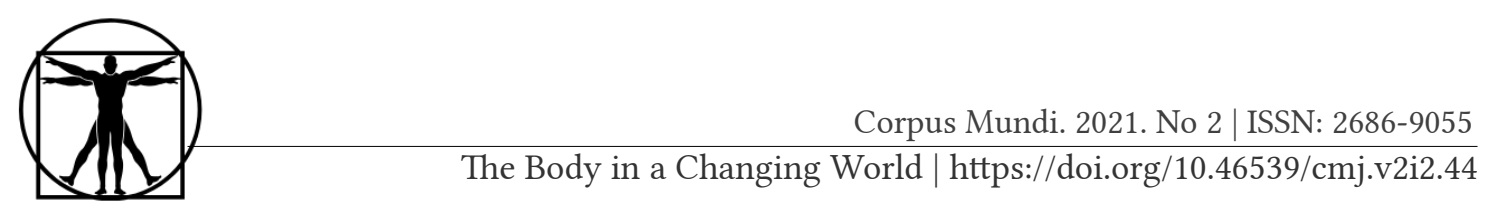

«Дьявол в мисс Джонс», с «Последним танго в Париже» (Harberski, p. 401).

Необходимо отметить не только то, насколько срослись «высокое» искусство андерграунда, мейнстримное кино, и якобы «низкопробное» порно, но и то, что они обеспечили, если хотите, своеобразное «прикрытие» для сексуальных сцен на экране. Независимо от того, считаете ли вы секс в фильме просто возбуждающим эротическим элементом или высокохудожественной попыткой снять настоящее порно, порнография также чревата рисками столкновения с претенциозностью, характерной для арт-кино. Эти взаимосвязи, и, по сути, само возникновение концепции «художественного порно» или «художественного фильма с элементами порно» варьируется от культуры к культуре. В Швеции легализация порнографии в 1960-е годы стала следствием импульса к сексуальному просвещению молодежи. Предполагалось, что будет налажен общий диалог о сексе, способствующий как улучшению общества, так и повышению качества порнофильмов (Larsson, p. 22). Когда художественное качество порнографии не повысилось, и она распространилась на другие сферы в виде терминов изобразительного искусства, в архитектуре, а также из-за кинотеатров и проституции, ответная реакция на порно привела к активизации женского движения в Швеции, которое было отчасти направлено на противодействие распространению порнографии (pp. 22-23). Тем не менее, либерализация Швецией законов относительно порно, безусловно, подпитывала восприятие Швеции, и скандинавских стран в целом, как стран с открытым отношением к сексу и сексуальности. Как утверждает Ларссон, «хотя Швеция воспринималась как сексуальный рай (или ночной кошмар), это восприятие было также гетеросексуальным и даже могло быть охарактеризовано как интернациональный мужской взгляд на нацию/объект женского пола, где женские модели и актрисы выступали символами национального проекта» (р. 22). Стремление просветить население в вопросах сексуальности, начавшееся еще в 1930-х гг., переросло к 1960-м гг. в определенный имидж страны, который и по сей день окружает Швецию и ее граждан. Важны и исторические подробности, поскольку в Швеции дети не рассматривались как нуждающиеся в защите от сексуального контента (в отличие от большинства стран), а сексуальная откровенность фильмов, которые ассоциируются со Швецией, была гетеросексуальной, и в них доминировали мужчины, которые соответственно и формировали этот образ для выражения своих желаний. Этот взгляд на скандинавскую сексуальность разделяет Ина Блом, отмечавшая, что скандинавская культура не драматизировала обнаженное тело. Здесь царил 
«деловой тон, в котором осуществлялось половое воспитание, неослабевающая вера в здоровое тело и глубокое недоверие к чему-либо, что связано с соблазнением, маскарадом или какой-либо привычной формой будуарной культуры» (р. 111). Эта традиция полового воспитания возникла непосредственно из женского движения за избирательные права (р. 112). Остается, пожалуй, понять, как «некогда критические и утопические» аспекты сексуальной свободы могли в течение последних сорока лет стать одержимы идеей о том, что тело сейчас является телом, обязательно подвергшимся насилию (р. 112). Секс сам по себе стал сексуальностью, что очень далеко от недраматичного и ориентированного на здоровую телесноориентированную сексуальность скандинавской чувственности. Трилогия Пазолини в Италии стала попыткой показать тела «римского люмпен-пролетария» или представителей молодежи Третьего мира, символизирующие тела из прошлого, что было призвано продемонстрировать его предположения, что в некоторых частях Европы и Ближнего Востока общества так мало изменились, что тела там столь же неиспорченны, как это могло быть в прошлом. Позднее Пазолини почти полностью «отказался» от этих фильмов, отчасти потому, что чувствовал в них следы современной идеологии, а отчасти потому, что они невольно породили жанр итальянского кинематографа, который использовал темы трилогии и их литературные источники, как предлог для создания хардкор-порно. Все три фильма Пазолини объединяет общий подход к кинематографу, который можно увидеть во всех его фильмах: симметричные композиции крупного плана, сосредоточенные на лице; использование натурных съемок, с акцентом на дизайне, архитектуре и топографии; запись звука после производства; литературные источники, являющиеся общественным достоянием ${ }^{1}$. Однако необычным в этих трех фильмах является то, что их объединяет особое внимание к телу, особенно подход к сексу, кажущемуся трогательно непосредственным и даже невинным. (MacCabe, 2012b, p. 25). Хотя именно эта чувственность и оказала наибольшее влияние, данные фильмы, как и все работы Пазолини - от его шедевра «Евангелие от Матфея» (1964) до посмертной ленты «Сало, или 120 дней Содома» (1975) - полностью ориентированы на разум, а не на тело (Bachmann, p. 61). Иными словами, фильмы Пазолини задуманы как форма политического реализма, особенно марксистского, так как в них выражена критика современности (MacCabe, 2012a, p. 51). Важнейшей целью каждого

1 Творчество Пазолини до Трилогии и в ее период отличалось экзотическими пейзажами Марокко для Эдипа, Турция для Медеи, а «Тысяча и одна ночь» снимались в нескольких местах, которые могли быть основой для оригинальных сказок. Эти фильмы похожи на сны, сказки внутри сказок (примечание автора) 


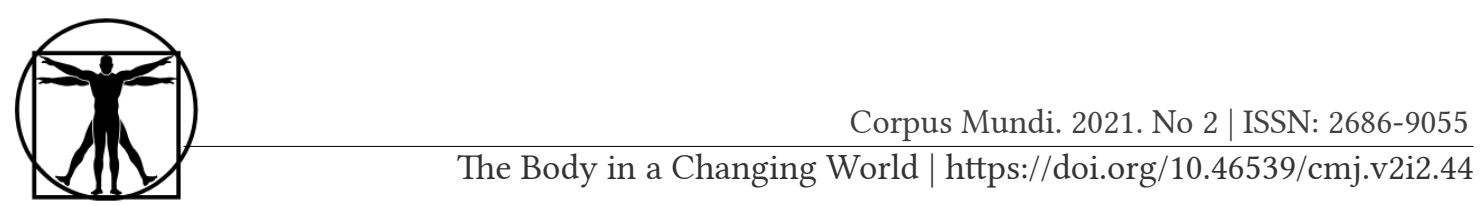

фильма для Пазолини было пробудить в зрителе момент самосознания, в ходе которого под влиянием прошлого происходит остранение ${ }^{1}$ настоящего, становящегося более понятным благодаря критике. Возможно, за исключением «Сало», эта цель так и не была достигнута, но его фильмы все еще интригуют нас, особенно в том, что изображают как мужские тела, так и женские, а однополый мужской секс часто показывается наравне с гетеросексуальным даже в прошлом ("Decamerotic", p. 29$)^{2}$.

Позднее Пазолини вынужден был написать эссе под названием «Трилогия отвергнутой жизни», в котором он признавал невозможность увидеть неиспорченное тело - тело, существовавшее до неолиберализма. Он, в частности, отторгал молодежь и, похоже, считал, что если его трилогия и поддерживала студенческое движение, то это было ошибкой, о которой он сожалеет. Буквальной реакцией с его стороны был фильм «Сало», продолживший тематику телесного, но переворачивающий все в Трилогии с ног на голову. Тело объективируется, но только для пыток и осквернения. Молодые тела буквально разрываются на части, а секс превращается в сексуальное насилие. Пазолини комментирует здесь не только Италию 1940-х годов, но и современность с принципиально иной точки зрения. Неолиберализм победил. Секс, молодость и тела полностью развращены. Сама жизнь потребляется, а телевидение превратило все в представление. Это проявляется в симметрии фильма и использовании средних планов, напоминающих телевизионную эстетику. Заключительная оргия насилия показана в фильме через бинокль, и мы видим эту сцену глазами садистов. Зрители оказываются соучастниками этого процесса. Жизнь - это ад, и все виновны в пособничестве фашистам. Данный фильм до сих пор является значительной вехой в развитии трансгрессии. Это также его лучший фильм, самый политизированный и самый обсуждаемый. Вероятно, у Пазолини лучше получалось со смертью, чем с жизнью, и с трагедией, чем с комедией. И не удивительно, что Сало планировался как первая лента новой «Трилогии Смерти».

Порнографическая вселенная для некоторых может показаться дистопией, однако она структурирована как чистая утопия. В своей фундаментальной работе по изучению порно (“Hard Core”) Линда Уильямс рассматривает порнофильмы как три высоко стилизованных

1 Автор использует термин "Defamiliarization" - так на английский переводится прием, предложенный Виктором Шкловским и направленный на деконструкцию текста и разрушение устоявшихся алгоритмов восприятия. Благодаря остранению зритель вынужден воспринимать предмет непривычным (п.п.)

2 Активное включение мужской телесности, в частности, содействовало реализации прав геев. Пазолини снимал мета-кино, как он выразился в одном интервью, и в первых двух фильмах позиционировал себя как художник (примечание автора) 
версии утопий, что перекликается с Ричардом Дайером (Richard Dyer): «Разделение, интеграция и разрушение» (р. 182). На момент выхода книги порнография двинулась в направлении, где женщины уже не были объектами, а являлись субъектами фильма - теми, кто описывал свои воспоминания или рассказывал историю о себе. В качестве примера она использует фильм Чэмберс 1980 г. «Ненасытная», показывающий звезду, которая вспоминает любовников, и пренебрегает камшотами ради своего удовольствия. Она ненасытна, потому что любит секс, и по сюжету, у нее есть иные причины, нежели мужские желания. Ее заботит ее собственное удовольствие - логичный итог, к которому движется пренебрегающий камшотом как конечной целью фильм.

Такую утопию можно увидеть именно в 1970-е годы, как ту, которая, возможно, все еще требует будущего. Еще до конца десятилетия дистопии начали идти параллельно, если вообще не доминировать над нашим представлением об утопии, и, можно сказать, что они были верны в своей оценке того, куда человечество движется в XXI веке. Можно утверждать, что утопический импульс, присутствующий в порнофильмах 1970-х годов, или, возможно, в порно в целом, которое нельзя назвать оптимистичным, представляет собой версию того, что Том Мойлан называет «критической утопией», являющейся «для читателя революционной, саморефлексивной, феминистской и политически мотивированной, а также политически преобразующей» (Jorgensen, p. 421). Все еще остается спорным вопрос о том, насколько после 1970-х гг. возможна позитивная утопия или утопия, находящая способ критиковать настоящее таким образом, чтобы показывать правдоподобный праксис. Может быть, она должна быть «постнациональной» (р. 421), и, вероятно, не может быть понята вне рамок политики 1960-х и 1970-х годов ${ }^{1}$. Как бы то ни было, понятие критической утопии может быть связано с интернализованной самокритикой, при которой идеализированное понятие утопии может быть отвергнуто или, по крайней мере, проанализировано. Порно 1970-х годов, вероятно, делает именно это, даже если оно представляет собой мир, в котором секс - это вопрос, а сексуальное знание, как своего рода объединяющая сила, может соединять пары для просмотра фильмов с наигранным стыдом. Как отмечает Линда Уильямс, главным сексуальным актом фильмов 1970-х годов был оральный секс, а именно минет (Williams, 1989, p. 150). Можно сказать, что если сам секс, или просто нагота, особенно мужская, стала видимой благодаря шведским

1 Более подробно на эту тему см. девятую главу нового издания «Demand the Impossible», в которой Мойлан говорит об этом применительно к Олдосу Хаксли. 


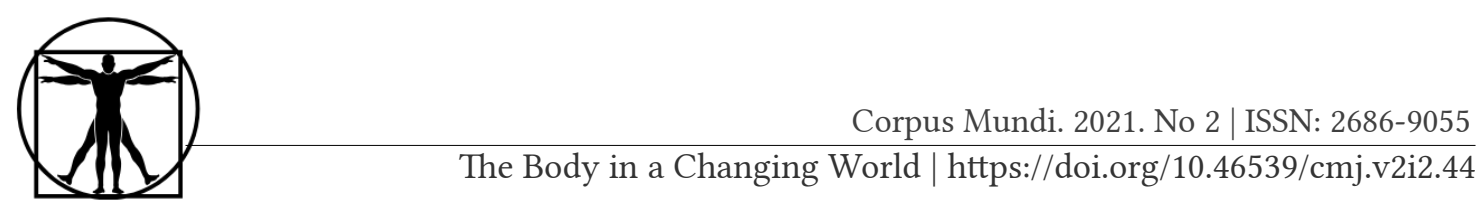

фильмам 1960-х гг. и европейскому арт-хаусу вообще, то к моменту появления «Глубокой Глотки» минет стал метонимией секса, а к выходу «Открытия Мисти Бетховен» был высмеян, превратившись в педагогическое пособие - правду о сексе, которая преподносится как правда о сексе. Другими словами, теперь это все старомодно. Иначе говоря, порно, как и любой жанр или субжанр, рефлексирует и критически относится к своим собственным практикам и предположениям.

Грань между тем, что можно назвать гей- и гетеропорно настолько тонка, что не всегда понятно, есть ли она вообще. По крайней мере, гетеропорно заигрывает с тематикой, особенно учитывая, что самые популярные порноактеры, как правило, определяют себя как «бисексуалы». Само собой разумеется, что это лишь вопрос времени, когда звезды женского и мужского пола появятся в сцене с кем-то одного с ними пола - предположительно, это было вопросом напряженности, но теперь такие условности стали своего рода шуткой. Для мужчин-звезд цена их боттоминга, возможно, связана с их статусом топов и длительностью времени, которое требуется на отказ от их однополой «девственности», будто бы в порно есть какая-то доля правы. Реальность такова, что между актерами и ролями, которые они играют, очень мало (если она вообще и есть) связи, хотя для некоторых фанатов, а может быть, и для некоторых исполнителей, иллюзия этой связи может быть и важна. Пожалуй, лучше рассматривать порно как совокупность жанров, где «пол» и «гендер» дают лишь намек на деятельность с ними связанную. Во всяком случае, как в случае с гетеропорно, некоторые из кинолент, определяемых как гей-порно, могут быть отнесены в область арт-хауса или, в случае с Фредом Холстедом, BDSM, или, возможно, в обе эти категории. Его ключевой фильм «В роли самого себя - Лос-Анджелес» (LA Plays Itself (1972)), в частности, скорее документальная картинка о проститутах Лос-Анджелеса, чем порнофильм, и представляет собой своего рода временной срез жизни города, уделяя почти столько же внимания экологическим изменениям, сколько и сексуальности. Наряду с Терри Саутом, работавшим со Стэнли Кубриком над проектом по созданию высокохудожественного порнофильма, который вероятно в последствии превратился в «С широко закрытыми глазами», Холстед рассматривался для проекта киноверсии «Диких мальчиков» (1971) Уильяма С. Берроуза (Jones, p. 85) ${ }^{1}$. Процесс превращения мейнстримового порно в массовое кино

1 Подробнее о «Диких мальчиках» см. шестую главу моей «Future Nostalgia: Performing David Bowie» 
не обошел стороной и гей-порно. Холстед был другом Кеннета Энгера (Kenneth Anger) и фанатом его классической работы «Восстание Скорпиона» (1963) (Jones, p. 86) ${ }^{1}$. Берроуз же был поклонником более позднего фильма Холстеда "Pieces of Eight" (1980) (p. 102). Любимым мейнстримовым голливудским режиссером Холстеда был Роберт Олтмен (р. 128). Возможно, гей-порно от гетеросексуального порно отличает то, что в первом «актеры - не «объекты», как женщины в гетеросексуальном порно, а скорее орудия секса, инструменты для разыгрывания фантазий, реализаторы мечтаний» (р. 128). Использование Холстедом BDSM образов и сценариев в “Sextool” и других проектах, возможно, свидетельствует об этом. В интервью 1979 года, Холстед дискутирует о распространении гомосексуальной тематики в мейнстримовых фильмах: бисексуальный персонаж Брэда Дэвиса в «Полуночном экспрессе» (1978) и Алан Стрэнг в пьесе Питера Шеффера «Эквус» (пьеса 1973; фильм 1977); (цит. по Jones, p. 163). Холстед стремился к совмещению жесткого гетеросексуального порно и гей-порно; он мог бы быть также и в более художественно задуманных порнофильмах, вроде «Империи чувств» Осимы (р. 165).

Если «Глубокую глотку» можно считать знаковым порнофильмом начала 1970-х гг., то «Парни в песке» (1971) могут рассматриваться как его гей-эквивалент. По мере того, как сексуальные практики вроде орального или анального секса за десятилетие превратились из экзотики в повседневность, это же произошло и с порнофильмами ${ }^{2}$. Точно так же, как сексуальные акты, типичные для гей-секса, стали частью гетеросексуального секса, гей-порно высокого класса, в практическом или воображаемом варианте, благодаря Холстеду приблизилось к тому, чтобы быть принятым в мейнстриме, хотя, возможно, отнюдь не в той степени, как это было с «Глубокой Глоткой» или «За Зеленой Дверью».

И хотя гей-темы в итоге проникли в массовое кино (от Кабаре (1972) до Разыскивающего (1980)), гей-порно мейнстримом не стало. Возможно, «Парни в песке» подошли к этому ближе всех, и, конечно же, их режиссер, Уэйкфилд Пул, как и Холстед, жаждал кроссовера. Фильм, в главной роли с Кейси Донована, похожим на Роберта Редфорда,

1 Ср. Йонас Мекас о «Пламенеющих созданиях»: «И все-таки, оглядываясь сейчас на «Пламенеющие создания», с учетом общего развития, он остается уникальным и классическим шедевром своего жанра, что проистекает от удивительной и неповторимой динамики, и кажется, что в нем сказано все, что только можно было сказать на эту тему, и никто не смог больше ничего добавить к этому». То же самое можно сказать и о «Рождестве на Земле» Барбары Рубин, и о «Песне любви» Жене, и о «Восходе Скорпиона» Энгера - они просто неповторимы, и они исследуют свои миры настолько глубоко и полностью, что больше нечего сказать на эту тему» (цит. по Jones, p. 117).

2 Есть богатая статистики по первому пункту, см., к примеру, Варгас-Купер. 
рассказывает о сексуальньх встречах с тремя разными мужчинами в трех разных местах на Файер Айленд: на пляже, у бассейна и внутри изысканного пляжного домика. По словам Синди Паттон, предполагалось, что у Донована больше всего шансов добиться успеха у публики в подобном кроссовере (р. 67). И хотя Донован был известен своей работой моделью и в кино, в конце концов, он стал высокооплачиваемым эскортом в Европе. Для Пула фильм, возможно, воплотил еще одну мечту начала 1970-х: пересечение границ не только мейнстрима и порно, но и гомо- и гетеросексуальных отношений ${ }^{1}$. В «Секс-гараже» (Sexgarage) Холстеда есть сцена гетеросексуального секса, как и в более поздних фильмах Пула. Кроме того, Пул всегда называл геев в фильме «Парни в песке» «утонченными», а не «раскрепощенными» (цит. по Patton, p. 69). Для Паттона "Парни в песке" были попыткой

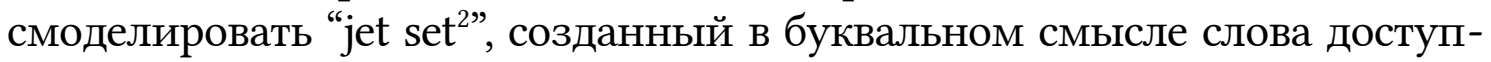
ностью путешествий реактивных на самолетах и «распутными» бисексуалами, которые считали себя выше общепринятой морали (69) ${ }^{3}$. Пул попытался создать свою собственную версию авангарда, возможно, более коммерческую, чем версия Уорхола, что-то, что могло бы зацепить его друзей-художников и дизайнеров (Patton, p. 71). Файер Айленд в его фильме изображен довольно элитарным местом, сексуальные контакты жутко изолированы и основаны на фантазиях. Здесь почти нет ощущения гей-сообщества, идентичности, находящейся вне мест, которые, кажется, взывают к актерам с помощью своего рода анимизма.

В то время как Пула можно критиковать за своего рода классовую конструкцию, в действительности он представлял BDSM аспекты мейнстримной гей-культуры, как, например, в сцене с Донованом, выходящим из воды с С-кольцом. Аналогичным образом, Пул оставляет последнюю и самую сложную сцену на межрасовое свидание, в котором Донован занимается сексом с афро-американским актером Томми Муром, играющий работника коммунальной службы, которого

1 Последний был снят в резиденции Нан Стибейн Шульц (Nan Stibane Schultz) в 1964 году, спроектированной Горацием Гиффордом. См. Роулинс. Напоминающий творения архитекторов Поля Рудольфа, Марселя Брейера и Луи Кана, этот дом из сучковатой сосны был выполнен в стиле модерн. Дом на дереве. Окна. Соблазнительная архитектура, словно гей-плейбой.

2 Jet set - «золотая молодежь», тусовщики, имевшие достаточно средств, чтобы путешествовать по миру на реактивных самолетах, посещая различные культурные мероприятия. Термин был введен американским журналистом русского происхождения Игорем Кассини в 50-х гг. (прим. редактора)

3 Во многом его жизнь перекликается с незавершенными «Услышанными молитвами» (1987) Трумена Капоте, где главным героем является бисексуал-свингер, который вращается не только в кругу гей-полусвета, но и среди ультра-богатых европейцев. Паттон называет «В роли самого себя - Лос-Анджелес» «кинематографическим романом с ключом» (р. 79). Подробнее об «Услышанных молитвах» см. мою дискуссию в четвертой главе «The aesthetics of self-invention» 
Донован приглашает в дом. Как рассказывает Пул в режиссерской версии фильма, Донован и Мур когда-то были любовниками, поэтому Пул специально выбрал Мура для этой сцены, верно предположив, что этим двум актерам будет комфортнее друг с другом, особенно в серии сцен, которые предполагают значительную долю фантазий со стороны персонажа Донована, представляющего себе секс с персонажем Мура до того, как Мур фактически подходит к двери.

Хотя можно сказать, что эти сцены закручены вокруг фантазий Донована о Муре, потому что тот черный, вместе с тем сцены между ними наделены значительной интимной близостью, которую не найдешь в других сексуальных сценах фильма. По ходу фильма секс переходит от одной формы к другой - обычного (на пляже) к атлетическому (у бассейна), и к изысканному, но в то же время эмоциональному (в доме). В каждом случае очевидно, что Пул продумал хореографию, и фильм однозначно креативен и проработан в своих сексуальных сценах, но самыми яркими являются сцены между Донованом и Муром. Если Холстед показал Лос-Анджелес как гей-рай на Западном побережье, то Пул годом ранее разместил эту нирвану на противоположном побережье. Оба были привязаны к месту, и хотя Холстед, возможно, отдавал дань уважения Пулу, Пул определенно пародировал The Boys in the Band (1968; фильм, 1970), поместивший гей-пробуждение в городскую обстановку, при которой экономические возможности крупного города обеспечивали независимость и анонимность, необходимые для каминг-аута. Фильм и пьеса видели в качестве цены этой свободы определенную долю неизбежной ненависти к себе. Пул и Холстед вины не чувствовали, но жаждали художественного смешения высокой и низкой культуры, а также размытия границ гетеро- и гомосексуальной культур. В обоих случаях они опережали свое время, и по этой причине могли видеть дальше своих коллег-натуралов, снимавших фильмы в 1970-х гг., пытаясь привнести порно в культуру мейнстрима.

\section{Список литературы}

Aydemir, M. (2007). Images of Bliss: Ejaculation, Masculinity, Meaning. Minneapolis: University of Minnesota Press.

Bachmann, G. (2012). Pasolini in Persia: The Shooting of 1,001 Nights. In P. P. Pasolini, Booklet. Trilogy of Life (pp. 55-61). The Criterion Collection.

Badiou, A. (2010). Infinite Thought: Truth and the Return to Philosophy (O. Feltham \& O. Clemens, Eds.). New York: Continuum.

Bazin, A. (1971). What Is Cinema? (H. Gray, Trans.). Berkeley: University of California Press. 
Bergman, I. (1960). The Virgin Spring. Janus Films.

Bertolucci, B. (1972). Last Tango in Paris. United Artists.

Blom, I. (2009). Carnal Knowledge: On "Whatever Happened to Sex in Scandinavia? Artforum, 47(7), 111-112.

Burroughs, W. S. (1971). The Wild Boys: A Book of the Dead. New York: Grove Press.

Capote, T. (2012). Answered Prayers. New York: Vintage International.

Church, D. (2018). Disposable Passions: Vintage Pornography and the Material Legacies of Adult Cinema. New York: Bloomsbury.

Cruz, A. (2016). The Color of Kink: Back Women, BDSM, and Pornography. New York: New York University Press.

Damiano, G. (1972). Deep Throat. Bryanston Distributing.

Damiano, G. (1973). The Devil in Miss fone. VCX Ltd. and MB Productions.

Fosse, B. (1972). Cabaret. Allied Artists.

Foucault, M. (1973). The Order of Things: An Archeology of the Human Sciences. New York: Vintage Books.

Friedkin, W. (1970). The Boys in the Band. National General Pictures.

Friedkin, William. (1980). Cruising. United Artists.

Genet, J. (1950). Un chant d'amour. Connoisseur Video.

Haberski, Jr., \& Raymond, J. (2014). Critics and the Sex Scene. In E. Schaefer (Ed.), Sex Scene: Media and the Sexual Revolution (pp. 383-406). Durham: Duke University Press.

Halsted, F. (1972a). LA Plays Itself.

Halsted, F. (1972b). Sex Garage.

Halsted, F. (1975). Sextool.

Halsted, F. (1980). Pieces of Eight.

Hamilton, G. (1971). Diamonds Are Forever. United Artists.

Huxley, A. (1932). Brave New World. London: Chatto and Windus.

Jones, W. E. (2011). Halsted Plays Himself. Los Angeles: Semiotext(e).

Jorgensen, D. (2015). Demand the Impossible: Science Fiction and the Utopian Imagination by Tom Moylan (review). Utopian Studies, 26(2), 419-421.

Kubrick, S. (1971). A Clockwork Orange. Warner Bros.

Kubrick, S. (1999). Eyes Wide Shut. Warner Bros.

Larsson, M. (2017). The Swedish Porn Scene: Exhibition Contexts, $8 \mathrm{~mm}$ Pornography and the Sex Film. Chicago: Intellect.

MacCabe, C. (2012a). Brave Old World. In P. P. Pasolini, Booklet. Trilogy of Life (pp. 49-53). The Criterion Collection.

MacCabe, C. (2012b). The Past Is Present. In P. P. Pasolini, Booklet. Trilogy of Life (pp. 19-25). The Criterion Collection.

Mapplethorpe, R. (1986). Black Book. New York: St. Martin’s Press.

Metzger, R. (1976). The Opening of Misty Beethoven. Catalyst Productions, Joy Near Pictures, and VCA Pictures. 
Metzger, R. (1977). Barbara Broadcast. Audubon Films, VCA Pictures, and Distribpix.

Meyer, R. (1965). Faster, Pussycat! Kill! Kill! RM Films International.

Mitchell, A., \& Mitchell, J. (1972). Behind the Green Door. Mitchell Brothers Film Group.

Moylan, T. (2014). Demand the Impossible: Science Fiction and the Utopian Imagination (R. Baccolini, Ed.). New York: Peter Lang.

Oshima, N. (1976). In the Realm of the Senses. Argos Films: Argos Films.

Parker, A. (1978). Midnight Express. Columbia Pictures.

Pasolini, P. P. (1964). The Gospel According to St. Matthew. Titanus Distribuzione.

Pasolini, P. P. (1971). The Decameron. United Artists.

Pasolini, P. P. (1972). The Canterbury Tales. United Artists.

Pasolini, P. P. (1974). Arabian Nights. United Artists.

Pasolini, P. P. (1975). Salò. United Artists.

Pasolini, P. P. (2012a). Booklet. "Trilogy of Life Rejected." In P. P. Pasolini, Trilogy of Life (pp. 915). The Criterion Collection,.

Pasolini, P. P. (2012b). Decamerotic. In Booklet. Trilogy of Life. By Pier Paolo Pasolini (pp. 2729). The Criterion Collection.

Patton, C. (2014). LA Plays Itself/Boys in the Sand. Vancouver: Arsenal Pulp Press.

Penn, A. (1967). Bonnie and Clyde. Warner Bros.-Seven Arts.

Poole, W. (1971). Boys in the Sand. Poolemar.

Pryor, B. (2015). X-Rated: The Greatest Adult Movies of All Time. Showtime.

Raphael, F. (1999). Eyes Wide Open: A Memoir of Stanley Kubrick. New York: Ballantine.

Rubin, B. (1963). Christmas on Earth.

Schlesinger, J. (1969). Midnight Cowboy. United Artists.

Schwabsky, B. (2008). Daring Intransigence. The Nation, 28-34.

Sjöman, V. (1967). I Am Curious (Yellow). Grove Press.

Sjöman, V. (1968). I Am Curious (Blue). Grove Press.

Smith, J. (1963). Flaming Creatures.

Soussloff, C. M. (2017). Foucault on Painting. Minneapolis: University of Minnesota Press.

Vargas-Cooper, N. (2011, January 18). Hard Core: The New World of Porn Is Revealing Eternal Truths about Men and Women. Retrieved from The Atlantic January/February 2011 website: http://www.theatlantic.com/magazine/print/2011/01/hard-core/8327/.

Waldrep, Sh. (2004). The Aesthetics of Self-Invention: Oscar Wilde to David Bowie. Minneapolis: University of Minnesota Press.

Waldrep, Sh. (2013). The Dissolution of Place: Architecture, Identity, and the Body. Farnham: Ashgate.

Waldrep, Sh. (2015). Future Nostalgia: Performing David Bowie. New York: Bloomsbury.

Williams, L. (1989). Hard Core: Power, Pleasure, and the "Frenzy of the Visible."Berkeley: University of California Press. 


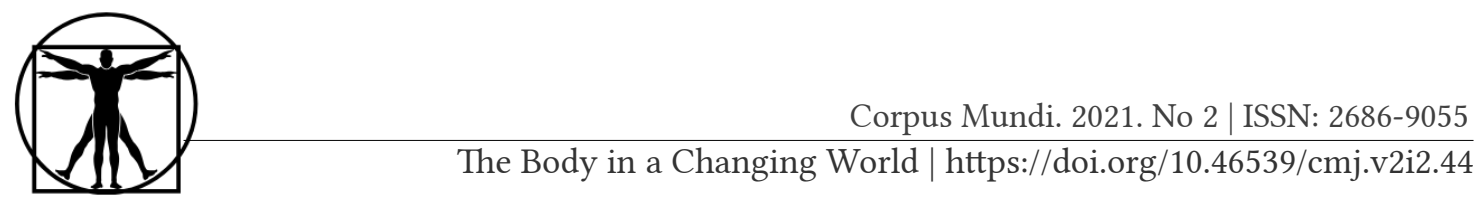

Williams, L. (2004). Skin Flicks on the Racial Border: Pornography, Exploitation, and Interracial Lust. In L. Williams (Ed.), Porn Studies (pp. 271-308). Durham: Duke University Press.

\section{References}

Aydemir, M. (2007). Images of Bliss: Ejaculation, Masculinity, Meaning. Minneapolis: University of Minnesota Press.

Bachmann, G. (2012). Pasolini in Persia: The Shooting of 1,001 Nights. In P. P. Pasolini, Booklet. Trilogy of Life (pp. 55-61). The Criterion Collection.

Badiou, A. (2010). Infinite Thought: Truth and the Return to Philosophy (O. Feltham \& O. Clemens, Eds.). New York: Continuum.

Bazin, A. (1971). What Is Cinema? (H. Gray, Trans.). Berkeley: University of California Press.

Bergman, I. (1960). The Virgin Spring. Janus Films.

Bertolucci, B. (1972). Last Tango in Paris. United Artists.

Blom, I. (2009). Carnal Knowledge: On "Whatever Happened to Sex in Scandinavia? Artforum, 47(7), 111-112.

Burroughs, W. S. (1971). The Wild Boys: A Book of the Dead. New York: Grove Press.

Capote, T. (2012). Answered Prayers. New York: Vintage International.

Church, D. (2018). Disposable Passions: Vintage Pornography and the Material Legacies of Adult Cinema. New York: Bloomsbury.

Cruz, A. (2016). The Color of Kink: Back Women, BDSM, and Pornography. New York: New York University Press.

Damiano, G. (1972). Deep Throat. Bryanston Distributing.

Damiano, G. (1973). The Devil in Miss Fone. VCX Ltd. and MB Productions.

Fosse, B. (1972). Cabaret. Allied Artists.

Foucault, M. (1973). The Order of Things: An Archeology of the Human Sciences. New York: Vintage Books.

Friedkin, W. (1970). The Boys in the Band. National General Pictures.

Friedkin, William. (1980). Cruising. United Artists.

Genet, J. (1950). Un chant d'amour. Connoisseur Video.

Haberski, Jr., \& Raymond, J. (2014). Critics and the Sex Scene. In E. Schaefer (Ed.), Sex Scene: Media and the Sexual Revolution (pp. 383-406). Durham: Duke University Press.

Halsted, F. (1972a). LA Plays Itself.

Halsted, F. (1972b). Sex Garage.

Halsted, F. (1975). Sextool.

Halsted, F. (1980). Pieces of Eight.

Hamilton, G. (1971). Diamonds Are Forever. United Artists.

Huxley, A. (1932). Brave New World. London: Chatto and Windus.

Jones, W. E. (2011). Halsted Plays Himself. Los Angeles: Semiotext(e). 
Jorgensen, D. (2015). Demand the Impossible: Science Fiction and the Utopian Imagination by Tom Moylan (review). Utopian Studies, 26(2), 419-421.

Kubrick, S. (1971). A Clockwork Orange. Warner Bros.

Kubrick, S. (1999). Eyes Wide Shut. Warner Bros.

Larsson, M. (2017). The Swedish Porn Scene: Exhibition Contexts, 8mm Pornography and the Sex Film. Chicago: Intellect.

MacCabe, C. (2012a). Brave Old World. In P. P. Pasolini, Booklet. Trilogy of Life (pp. 49-53). The Criterion Collection.

MacCabe, C. (2012b). The Past Is Present. In P. P. Pasolini, Booklet. Trilogy of Life (pp. 19-25). The Criterion Collection.

Mapplethorpe, R. (1986). Black Book. New York: St. Martin's Press.

Metzger, R. (1976). The Opening of Misty Beethoven. Catalyst Productions, Joy Near Pictures, and VCA Pictures.

Metzger, R. (1977). Barbara Broadcast. Audubon Films, VCA Pictures, and Distribpix.

Meyer, R. (1965). Faster, Pussycat! Kill! Kill! RM Films International.

Mitchell, A., \& Mitchell, J. (1972). Behind the Green Door. Mitchell Brothers Film Group.

Moylan, T. (2014). Demand the Impossible: Science Fiction and the Utopian Imagination (R. Baccolini, Ed.). New York: Peter Lang.

Oshima, N. (1976). In the Realm of the Senses. Argos Films: Argos Films.

Parker, A. (1978). Midnight Express. Columbia Pictures.

Pasolini, P. P. (1964). The Gospel According to St. Matthew. Titanus Distribuzione.

Pasolini, P. P. (1971). The Decameron. United Artists.

Pasolini, P. P. (1972). The Canterbury Tales. United Artists.

Pasolini, P. P. (1974). Arabian Nights. United Artists.

Pasolini, P. P. (1975). Salò. United Artists.

Pasolini, P. P. (2012a). Booklet. “Trilogy of Life Rejected.” In P. P. Pasolini, Trilogy of Life (pp. 915). The Criterion Collection,.

Pasolini, P. P. (2012b). Decamerotic. In Booklet. Trilogy of Life. By Pier Paolo Pasolini (pp. 27-

29). The Criterion Collection.

Patton, C. (2014). LA Plays Itself/Boys in the Sand. Vancouver: Arsenal Pulp Press.

Penn, A. (1967). Bonnie and Clyde. Warner Bros.-Seven Arts.

Poole, W. (1971). Boys in the Sand. Poolemar.

Pryor, B. (2015). X-Rated: The Greatest Adult Movies of All Time. Showtime.

Raphael, F. (1999). Eyes Wide Open: A Memoir of Stanley Kubrick. New York: Ballantine.

Rubin, B. (1963). Christmas on Earth.

Schlesinger, J. (1969). Midnight Cowboy. United Artists.

Schwabsky, B. (2008). Daring Intransigence. The Nation, 28-34.

Sjöman, V. (1967). I Am Curious (Yellow). Grove Press.

Sjöman, V. (1968). I Am Curious (Blue). Grove Press.

Smith, J. (1963). Flaming Creatures. 


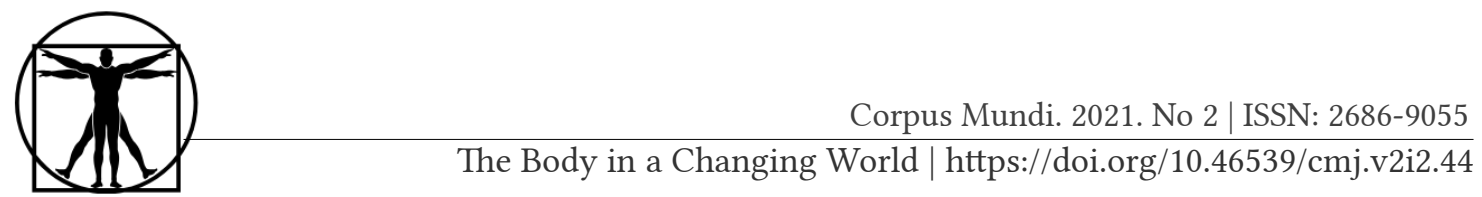

Soussloff, C. M. (2017). Foucault on Painting. Minneapolis: University of Minnesota Press.

Vargas-Cooper, N. (2011, January 18). Hard Core: The New World of Porn Is Revealing Eternal Truths about Men and Women. Retrieved from The Atlantic January/February 2011 website: http://www.theatlantic.com/magazine/print/2011/01/hard-core/8327/.

Waldrep, Sh. (2004). The Aesthetics of Self-Invention: Oscar Wilde to David Bowie. Minneapolis: University of Minnesota Press.

Waldrep, Sh. (2013). The Dissolution of Place: Architecture, Identity, and the Body. Farnham: Ashgate.

Waldrep, Sh. (2015). Future Nostalgia: Performing David Bowie. New York: Bloomsbury.

Williams, L. (1989). Hard Core: Power, Pleasure, and the "Frenzy of the Visible."Berkeley: University of California Press.

Williams, L. (2004). Skin Flicks on the Racial Border: Pornography, Exploitation, and Interracial Lust. In L. Williams (Ed.), Porn Studies (pp. 271-308). Durham: Duke University Press. 